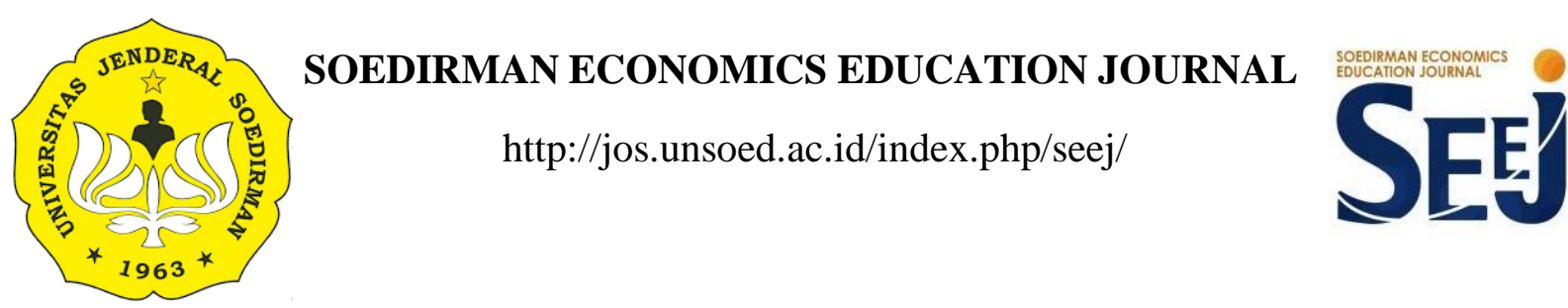

\title{
PENGARUH STUDENT ENGAGEMENT DAN KEMAMPUAN LOGIS MATEMATIS TERHADAP PRESTASI BELAJAR DIMODERASI PERSEPSI KOMPETENSI GURU
}

\author{
MOHAMAD ARIEF NURDIANSYAH ${ }^{1}$, SITI ZULAIKHA WULANDARI ${ }^{1}$, RATNO PURNOMO ${ }^{1}$ \\ ${ }_{1}^{1}$ Pendidikan Ekonomi, Fakultas Ekonomi dan Bisnis, Universitas Jenderal Soedirman, Purwokerto 53121, Indonesia \\ Email : areefdamahom@gmail.com
}

\begin{abstract}
Abstrak
Keberhasilan belajar berasal dari Faktor internal yaitu student engagement dan kemampuan logis matematis serta faktor eksternal yaitu kompetensi guru. Penelitian ini bertujuan untuk menganalisis pengaruh pengaruh student engagement, kemampuan logis matematis, dan persepsi mengenai kompetensi guru terhadap prestasi belajar yang memoderasi pengaruh student engagement dan kemampuan logis matematis terhadap prestasi belajar. Penelitian ini merupakan penelitian kuantitatif dengan jenis penelitian eksplanatori menggunakan metode survei. Populasi dalam penelitian ini berasal dari kelas XI IPA dan XI IPS dengan jumlah 128 peserta didik. Teknik pengambilan sampel menggunakan random sampling dengan alokasi proporsional. Teknik analisis data menggunakan analisis regresi berganda, regresi moderasi, uji F, dan uji T. Hasil penelitian menunjukkan (1) keterlibatan peserta didik berpengaruh positif dan signifikan terhadap prestasi belajar (2) kemampuan logis matematis berpengaruh positif dan signifikan terhadap prestasi belajar (3) persepsi mengenai kompetensi guru berpengaruh positif dan signifikan terhadap prestasi belajar (4) persepsi mengenai kompetensi guru memoderasi pengaruh keterlibatan peserta didik terhadap prestasi belajar (5) persepsi mengenai kompetensi guru memoderasi pengaruh kemampuan logis matematis terhadap prestasi belajar.
\end{abstract}

Kata Kunci: Keterlibatan, Kemampuan Logis Matematis, Prestasi Belajar, Kompetensi Guru.

\begin{abstract}
The learning success is effected by internal factors namely students engagement and mathematical logical abilities and external factors namely teacher's competencies. This study aims to analyze the effect of student engagement, mathematical logical ability, perceptions on teacher's competencies that moderated by the effect of student engagement and mathematical logical ability on learning achievement. This research is a quantitative research with explanatory research type used survey method. The population in this research from XI IPA and XI IPS with 128 students. The sampling technique used proportioned random sampling. The data analysis technique used multiple regression analysis, moderation regression, $\mathrm{F}$ test, and $\mathrm{T}$ test. The results shown: (1) there is a possitive significant effect of student engagement on learning achievement (2) there is a possitive significant effect mathematical logical ability on learning achievement (3) there is a possitive significant effect perceptions of teacher's competencies on learning achievement (4) the perceptions of teacher's competencies moderated the effect of student engagement on learning achievement (5) the perceptions of teacher's competencies moderated the effect of mathematical logical ability on learning achievement.
\end{abstract}

Keywords: Student Engagement, Mathematical Logical Ability, Learning Achievement, Teacher's Competencies. 


\section{PENDAHULUAN}

\section{Latar Belakang}

Prestasi belajar dalam Slameto (2010:54) disebut juga sebagai keberhasilan belajar. Keberhasilan belajar dianggap sebagai suatu yang penting, karena keberhasilan tersebut dijadikan acuan dan standar sekolah untuk meningkatkan prestasi belajar. Asrul et.al (2014:197) menjelaskan bahwa Standar penilaian pendidikan adalah kriteria mengenai mekanisme, prosedur, dan instrumen penilaian hasil belajar peserta didik. Penilaian pendidikan sebagai proses pengumpulan dan pengolahan informasi untuk mengukur pencapaian hasil belajar peserta didik. Standar penilaian tersebut selanjutnya ditetapkan menjadi KKM (kriteria ketuntasan minimal) yang mesti dipenuhi sebagai syarat ketuntasan mata pelajaran yang ditempuh oleh peserta didik dalam satu tahun pelajaran atau 2 semester.

MAN 1 Banyumas merupakan satuan pendidikan formal yang menyelenggarakan proses pembelajaran dengan standar penilaian pendidikan. Salah satu mata pelajaran yang dinilai adalah ekonomi (peminatan dan lintas minat). Penilaian prestasi belajar ekonomi di MAN 1 Banyumas diujikan pada penilaian tengah semester dan penilaian akhir semester dengan menerapkan standar KKM yang telah ditentukan yaitu 71. Akan tetapi terdapat masalah dalam pemenuhan standar KKM tersebut. Berikut merupakan tabel prestasi belajar berupa nilai penilaian akhir semester (PAS) ganjil 2019/2020 mata pelajaran ekonomi kelas 11:

Tabel 1. Nilai PAS Ganjil 2019-2020 Mata Pelajaran Ekonomi

\begin{tabular}{ccccccc}
\hline NO & Kelas & KKM & $\begin{array}{c}\text { Jumlah Peserta } \\
\text { Didik }\end{array}$ & Rata-rata & $\begin{array}{c}\text { Belum } \\
\text { Tuntas }\end{array}$ & $\begin{array}{c}\text { Sudah } \\
\text { Tuntas }\end{array}$ \\
\hline 1 & XI IPA 2 & 71 & 30 & 70,53 & $14(46 \%)$ & $16(53 \%)$ \\
2 & XI IPA 3 & 71 & 33 & 70 & $15(45 \%)$ & $18(55 \%)$ \\
3 & XI IPS 2 & 71 & 31 & 67,02 & $24(77 \%)$ & $7(23 \%)$ \\
4 & XI IPS 3 & 71 & 35 & 69,14 & $22(62 \%)$ & $13(38 \%)$ \\
\hline & Jumlah & & 129 & 69,17 & $75(58 \%)$ & $54(42 \%)$ \\
\hline
\end{tabular}

Sumber : Data Penilaian Akhir Semester Ganjil Guru Mata Pelajaran Ekonomi Tahun Pelajaran $2019 / 2020$

Berdasarkan tabel 1. Dapat diketahui bahwa secara keseluruhan, terdapat masalah prestasi belajar yaitu ke-4 kelas di atas masih belum tuntas dalam proses pembelajaran ekonomi. Jumlah peserta didik kelas 11 yang memenuhi KKM (sudah tuntas) yaitu sebanyak 54 peserta didik atau $42 \%$ dari jumlah peserta didik, sedangkan Jumlah peserta didik yang tidak memenuhi KKM (belum tuntas) memiliki jumlah lebih banyak yaitu sebanyak 75 peserta didik atau $58 \%$ dari jumlah peserta didik. Banyaknya peserta didik yang belum tuntas menunjukkan bahwa prestasi belajar peserta didik belum sepenuhnya optimal. Pemilihan antara kedua jenis kelas (peminatan IPS dan lintas minat IPA) tersebut dikarenakan kedua kelas memiliki input peserta didik yang relatif homogen. Akan tetapi, pada kelas IPA yang basisnya adalah eksakta menunjukkan gejala 
yang lebih besar dalam penuntasan mata pelajaran ekonomi kelas XI yang sebagian besar memuat kompetensi dasar menghitung dan penalaran. Sedangkan kedua kelas tersebut mendapatkan materi ekonomi yang tidak jauh berbeda dengan kompetensi dasar yang sama. Penyebab masalah prestasi belajar menurut slameto (2010:54) berasal dari dalam diri peserta didik seperti faktor jasmaniah dan psikologis serta faktor di luar diri peserta didik seperti lingkungan sekolah, masyarakat, dan khususnya keluarga.

Dari beberapa faktor yang melatar belakangi rendahnya prestasi belajar tersebut berasal dari secara dominan berasal dari faktor internal yaitu keterlibatan peserta didik dan kemampuan logis matematis serta berasal dari faktor eksternal yaitu persepsi mengenai kompetensi guru. Berdasarkan observasi dan hasil wawancara yang dilakukan ketika peneliti melaksanakan praktik pengalaman lapangan (PPL), diketahui bahwa lebih dari 50\% peserta didik ( $>570$ ) merupakan santri pondok pesantren yang ketika belajar tidak melibatkan dirinya baik itu perilaku, pikiran, dan emosinya. Ketidak terlibatan peserta didik ditunjukkan dengan seringnya tertidur pada saat pelajaran, tidak mengerjakan tugas, merasa terbebani untuk belajar. Selain itu, rata-rata peserta didik kesulitan saat menemui jenis soal penalaran dan matematika, hal tersebut ditunjukkan dengan nilai penilaian akhir madrasah yang rendah khususnya mata pelajaran ekonomi yang memuat kedua jenis pemahaman konseptual tersebut, berbeda dengan peserta didik yang mengikuti kompetisi sains madrasah dan memiliki hasil tes kemampuan dasar dan psikotes kecerdasan logis matematis di atas rata-rata cenderung lebih mudah mengerjakan soalsoal tersebut. Faktor eksternal yang mempengaruhi prestasi belajar adalah kompetensi guru. Seorang guru yang kompeten tentunya dapat mengelola kelas dan menstimulasi keterlibatan peserta didik dan kemampuan logis matematis peserta didik agar lebih baik lagi.

Laporan The Programme for International Student Assessment (PISA, 2018) faktor yang dapat menyebabkan penurunan prestasi belajar adalah penyimpangan yang terjadi pada keterlibatan atau keterikatan peserta didik dalam proses belajar. Penyimpangan yang dimaksud adalah ketika peserta didik tidak merasakan dirinya merupakan bagian dari sekolah dan kelas yang ditunjukkan dengan perilaku, sikap, dan pikiran mereka. Bariyah dan Pierewan (2017) menyebutkan bahwa peserta didik yang terlibat (engaged) dalam belajar memiliki antusiasme dan menempatkan dirinya untuk giat belajar agar dapat meningkatkan prestasi belajar dari peserta didik itu sendiri. Sedangkan menurut Appleton et al. (2008) menjelaskan kondisi peserta didik yang tidak terlibat (unengaged) dalam belajar cenderung bersikap apatis, tidak bersemangat, mengobrol dengan teman, serta tidak fokus atau bahkan tidur saat pelajaran berlangsung yang mengakibatkan tidak tersampaikannya pembelajaran dengan baik.

Faktor lain yang dapat menurunkan prestasi belajar peserta didik dalam laporan PISA (2018) adalah kemampuan berpikir logis dan matematis. Menurut Pasaribu (2016) peserta didik yang memiliki kemampuan logis-matematis yang rendah akan merasakan kesulitan selama 
proses pembelajaran. Rendahnya kemampuan logis-matematis peserta didik mengakibatkan proses pembelajaran yang berbasis penalaran dan konseptual matematis seperti ekonomi mengalami kendala dan masalah dalam proses pembelajaran. Selain itu, menurut Sihombing (2017) peserta didik yang memiliki pemikiran logis selalu ada rasa ingin tahu, rasa penasaran, dan selalu ingin membuktikan. Peserta didik yang kurang berpikir logis akan selalu menginginkan hal yang praktis tanpa memikirkan apakah dia mengerti dan memahami materi atau pelajaran ekonomi tersebut, sehingga akan berpengaruh dengan prestasi belajar ekonomi peserta didik tersebut. Peserta didik yang memiliki kecerdasan logis matematis yang tinggi cenderung akan lebih mudah memahami suatu masalah dan menyelesaikannya dengan tepat.

Permasalahan rendahnya kemampuan logis-matematis dan keterlibatan belajar peserta didik (student engagement) dapat teratasi jika peran dari guru untuk menstimulus masalah tersebut dengan kompetensi bisa berjalan dengan baik. Dalam laporan Teaching and Learning International Survey (TALIS-PISA, 2018) menyebutkan bahwa peran seorang guru dalam mempengaruhi proses pembelajaran sangatlah penting. Dalam mendukung proses pembelajaran perlu adanya pengelolaan kelas, dukungan guru, kejelasan pengajaran atau petunjuk, dan pengaktifan kognisi atau pengetahuan dari peserta didik. Kunter et al. (2013) menyatakan kompetensi guru yang profesional tersebut dapat memengaruhi hasil belajar (outcomes) dan kesenangan (enjoyment) terhadap pelajaran tertentu sehingga peserta didik tersebut dapat terlibat dan berpartisipasi secara aktif. Selain itu, seorang guru kompeten juga dapat meningkatkan kemampuan berpikir dari peserta didik. Dalam penelitian Ahmad (2018) menjelaskan bahwa kompetensi guru menurut peserta didik mempunyai peranan penting khususnya dalam meningkatkan kemampuan analitik peserta didik.

\section{Tujuan Penelitian}

Tujuan dalam penelitian ini adalah untuk menganalisis (1) pengaruh keterlibatan peserta didik terhadap prestasi belajar (2) pengaruh kemampuan logis matematis berpengaruh positif dan signifikan terhadap prestasi belajar (3) pengaruh persepsi mengenai kompetensi guru terhadap prestasi belajar (4) pengaruh keterlibatan peserta didik terhadap prestasi belajar dimoderasi persepsi mengenai kompetensi guru (5) pengaruh kemampuan logis matematis terhadap prestasi belajar dimoderasi persepsi mengenai kompetensi guru.

\section{Ruang Lingkup Penelitian}

Penelitian ini akan dibatasi permasalahannya pada analisis pengaruh kemampuan logis matematis dan keterlibatan belajar (student engagement) terhadap prestasi belajar mata pelajaran ekonomi pada kelas XI peminatan (IPS) dan lintas minat (IPA) di MAN 1 Banyumas yang dimoderasi oleh persepsi peserta didik tentang kompetensi guru. 


\section{TINJAUAN PUSTAKA DAN PERUMUSAN HIPOTESIS}

\section{Teori Prestasi Belajar}

Walberg (1992) prestasi akademik atau prestasi belajar adalah karakteristik psikologis siswa secara individu dan lingkungan psikologis langsungnya mempengaruhi hasil pendidikan (kognitif, perilaku, dan sikap). Dalam Slameto (2019:25) menjelaskan bahwa terdapat 5 jenis teori prestasi belajar dari peserta didik yang diadopsi dari teori Morrone dan Schutz (2003) diantaranya teori sosial kognitif (social cognitive theory) yang merupakan proses belajar sosial dengan faktor-faktor kognitif dan perilaku yang mempengaruhi prestasi belajar peserta didik, teori motivasi instrinsik dan determinasi atau tekad diri (intrinsic motivation and self determination), teori nilai tugas (task value theory), teori atribusi atau macam-macam kemampuan yang dimiliki (atribution theory), dan teori tujuan berprestasi (achievement goal theory).

\section{Teori Keterlibatan Peserta Didik}

Barkley (2009:5) mendefinisikan keterlibatan peserta didik sebagai frekuensi di mana peserta didik berpartisipasi dalam kegiatan yang merepresentasikan praktik pendidikan yang efektif, dan menganggapnya sebagai pola keterlibatan dalam berbagai kegiatan dan interaksi baik di dalam maupun di luar kelas dan sepanjang proses pembelajaran peserta didik. Terdapat dua jenis keterlibatan (engagement) yaitu keterlibatan dengan sekolah dan keterlibatan dengan kelas. Goodenow (1992) menjelaskan keterlibatan dengan sekolah ditunjukkan oleh perasaan peserta didik yang menggap bahwa mereka diterima, didukung dan dilibatkan oleh orang lain dalam lingkungan sosial kampus atau sekolah (siswa lain, guru, dan sebagainya). Selain itu, keterlibatan dengan kelas menurut Gunuc (2014) proses terlibatnya peserta didik pada 3 aspek keterlibatan (engagement) dalam pelajaran yaitu behavioral engagement atau keterlibatan perilaku, emotional engagement atau keterlibatan secara emosional, dan cognitive engagement atau secara kognitif.

\section{Teori Kemampuan Logis Matematis}

Kemampuan logis matematis merupakan salah satu cabang dari 8 kecerdasan universal. Teori tersebut merupakan teori dari Gardner (1993:137) yang menjelaskan kecerdasan logismatematis sebagai kemampuan penalaran ilmiah, perhitungan secara matematis, berpikir logis, penalaran induktif atau deduktif, dan ketajaman pola-pola abstrak serta hubungan-hubungan (kemampuan korelasional). Teori tersebut dikembangkan oleh Amstrong (2014:2) sebagai suatu kemampuan atau kapasitas individu dalam mengelola angka dengan efektif seperti pada matematika, perpajakan, akuntansi, atau statistik dan sebagainya. Serta kemampuan atau kapasitas dalam penalaran yang baik pada tiap kasus atau masalah yang dihadapi seperti pada sains, pemrograman, dan logika. kecerdasan ini mencakup kepekaan terhadap pola dan hubungan logis, pernyataan dan preposisi, fungsi, dan juga abstraksi. Jenis proses kognisi yang 
dapat dilakukan oleh kecerdasan logis-matematis meliputi kategorisasi, klasifikasi, inferensi, generalisasi, perhitungan, dan pengujian hipotesis.

\section{Teori Persepsi dan Kompetensi Guru}

Dalam Salisah (2015:30) persepsi adalah pemaknaan atau arti terhadap informasi (energi/stimulus) yang masuk ke dalam kognisi atau pengetahuan manusia menjadi berbagai sudut pandang (point of view). Solso et.al (2013:134) menjelaskan bahwa terdapat dua jenis persepsi yaitu persepsi konstruktif dan persepsi langsung. Persepsi konstruktif pada peserta didik didasarkan pada pemberian penilaian atau persepsi oleh peserta didik terhadap guru melalui pengalaman empiris yang didapatkan pada saat pembelajaran telah berlalu. Sedangkan persepsi langsung pada peserta didik didasarkan pada pemberian penilaian atau persepsi oleh peserta didik terhadap guru melalui sensasi dan ingatan secara langsung.

Kompetensi guru dalam UU No 14 tahun 2005 adalah seorang guru yang memiliki kompetensi pedagogik, kompetensi kepribadian, kompetensi sosial, dan kompetensi profesional yang diperoleh melalui pendidikan profesi yang ditandai dengan dimilikinya SK guru profesional atau sertifikasi baik melalui PLPG (pendidikan latihan profesi guru) maupun PPG (pendidikan profesi guru). Guru yang kompeten tersebut adalah guru yang memiliki kemampuan atau kompetensi untuk diimplementasikan dalam pengelolaan kelas (classroom management), pemahaman mengenai hal yang diajarkan, serta penggunaan waktu yang baik (Creemers et al. 2013:26 Guru yang memiliki kompetensi dalam Cooper (2010:25) disebut guru profesional. Guru tersebut harus menyadari tiap perkembangan yang diharapkan dan rentang variasi individu dalam setiap domain (fisik, sosial, emosional, moral, dan kognitif) serta dapat mengidentifikasi tingkat kesiapan dalam belajar, dan memahami bagaimana pengembangan dalam satu domain dapat memengaruhi kinerja di domain lain.

\section{PERUMUSAN HIPOTESIS}

\section{Pengaruh Keterlibatan Peserta Didik (Student Engagement) terhadap Prestasi Belajar Peserta Didik.}

Apabila peserta didik memiliki keterlibatan atau keterikatan (student engagment) dalam proses pembelajaran maka dapat menghasilkan prestasi belajar yang baik. Peserta didik dapat dikatan memilikin keterlibatan ketika peserta didik tersebut menunjukkan rasa memiliki terhadap sekolah, melibatkan sisi emosional, melibatkan perilaku yang baik, serta terlibatnya pikiran (kognisi atau pengetahuan) selama proses belajar berlangsung. Hal tersebut dibuktikan dalam penelitian Bariyah dan Pieriwan (2017) yang menyebutkan bahwa keterlibatan peserta didik memiliki pengaruh yang positif dan signifikan prestasi belajar. serta dalam penelitian Gunuc (2014) yang menyebutkan bahwa keterlibatan dengan sekolah dan kelas memiliki pengaruh yang positif dan signifikan terhadap prestasi akademik peserta didik. 
H1 : Keterlibatan peserta didik berpengaruh signifikan terhadap prestasi belajar

\section{Pengaruh Kemampuan Logis Matematis Terhadap Prestasi Belajar}

Kemampuan atau kecerdasan logis-matematis merupakan tersebut ditunjukkan dengan kemampuan dalam operasi hitung dan kemampuan penalaran ilmiah atau logika silogisme. Kecerdasan tersebut dapat menunjang peserta didik untuk mendapatkan hasil belajar (learning outcomes) yang optimal khususnya pada mata pelajaran dengan kategori analisis teorikal dan matematis. Hal tersebut dibuktikan dalam penelitian Wulansari dan Hakim (2015) yang menunjukkan bahwa kemampuan logis-matematis secara parsial dan simultan memberikan pengaruh yang positif dan siginfikan terhadap pemahaman akuntansi peserta didik. Selain itu, dalam penelitian Sihombing (2016) yang menunjukkan bahwa kecerdasan matematis-logis dan gaya belajar kinestetik peserta didik menunjukkan pengaruh positif dan signifikan terhadap prestasi belajar ekonomi peserta didik. Serta dalam penelitian Pasaribu (2016) juga menjelaskan bahwa kemandirian belajar dan kecerdasan logis matematis menunjukkan hubungan yang positif dan signifikan terhadap prestasi belajar peserta didik.

H2 : Kemampuan logis matematis berpengaruh signifikan terhadap prestasi belajar

\section{Pengaruh Keterlibatan Peserta Didik (Student Engagement) dan Kemampuan Logis Matematis terhadap Prestasi Belajar Dimoderasi Persepsi Mengenai Kompetensi Guru}

Solso et al. (2013:134) menjelaskan bahwa terdapat dua macam persepsi yaitu persepsi langsung dan persepsi konstruktif. Kedua persepsi tersebut digunakan dalam melakukan penilaian terhadap fenomena yang terjadi. Dalam proses pembelajaran, persepsi langsung dialami oleh peserta didik saat proses pembelajaran berlangsung melalui perasaan (sense) dan ingatan (memorize). Sedangkan, persepsi konstruktif dialami oleh peserta didik setelah melalui proses pembelajaran atau disebut dengan pengalaman belajar. Persepsi mengenai kompetensi guru tersebut dalam penelitian Hakim (2015) menunjukkan bahwa kompetensi guru memberikan kontribusi positif dan signifikan terhadap prestasi belajar. Sedangkan Prihantoro et.al (2019) menyatakan bahwa persepsi peserta didik mengenai kompetensi guru berpengaruh secara positif dan signifikan terhadap hasil belajar.

Kompetensi guru dalam Creemers et al. (2013:26) diimplementasikan dalam bentuk pengelolaan kelas (classroom management), pemahaman mengenai hal yang diajarkan, serta penggunaan waktu yang baik. Seorang guru yang kompeten akan menstimulasi peserta didik untuk aktif terlibat dalam dan meningkatkan memotivasi dari peserta didik untuk dapat meningkatkan prestasi belajar. Penelitian Meilinda dan Aulia (2017) menjelaskan persepsi tentang kompetensi pedagogik guru matematika berkontribusi terhadap keterikatan peserta didik pada pelajaran matematika. Selain itu dalam penelitian Kheruniah (2013) menunjukkan bahwa kompetensi kepribadian guru memberikan kontribusi positif dan signifikan terhadap 
motivasi belajar dan kedisiplinan belajar peserta didik. serta dalam penelitian Mujianto (2010) motivasi belajar mampu memperkuat pengaruh persepsi peserta didik tentang kompetensi pedagogik guru dan hasil belajar peserta didik. Serta, persepsi siswa tentang kompetensi pedagogik guru berpengaruh signifikan terhadap hasil belajar dan motivasi belajar peserta didik.

Cooper (2010:373) menjelaskan bahwa seorang guru yang kompeten dapat menstimulasi prestasi belajar melalui metode, bahan ajar, dan alat evaluasi. Prestasi belajar optimal didapatkan peserta didik melalui stimulasi yang dilakukan oleh seorang guru untuk mengaktifkan kognisi atau kemampuan berpikir peserta didik. pernyataan tersebut dibuktikan dalam penelitian Wulandari (2012) yang menyebutkan bahwa prestasi belajar mampu memperkuat pengaruh kompetensi pedagogik dan kompetensi profesional guru terhadap literasi ekonomi. Ahmad (2018) persepsi Siswa tentang Kompetensi Pedagogik Guru mempengaruhi kemampuan berpikir analitik peserta didik secara positif. Kunter et al. (2013) kompetensi profesional guru menunjukkan pengaruh positif terhadap hasil belajar dan kemampuan matematis peserta didik. Serta Jentsch dan Schlesinger (2017) menjelaskan bahwa pengelolaan kelas, dukungan pembelajaran mandiri, aktivasi kognitif, dan kualitas pembelajaran menunjukkan pengaruh yang positif terhadap prestasi belajar peserta didik.

Berdasarkan telaah pustaka dan hasil penelitian terdahulu, dapat dirumuskan hipotesis penelitian ini sebagai berikut :

H3 : Persepsi mengenai kompetensi guru berpengaruh signifikan terhadap prestasi belajar

$H 4$ : Persepsi peserta didik tentang kompetensi guru memoderasi pengaruh keterlibatan peserta didik (student engagement) terhadap prestasi belajar

H5 : Persepsi peserta didik tentang kompetensi guru memoderasi pengaruh kemampuan logis matematis peserta didik terhadap prestasi belajar

\section{METODE PENELITIAN}

Penelitian ini merupakan penelitian kuantitatif dengan jenis penelitian eksplanatori menggunakan metode survei. Populasi dalam penelitian ini berasal dari kelas XI IPA dan XI IPS dengan jumlah 128 peserta didik. Teknik pengambilan sampel menggunakan random sampling dengan alokasi proporsional, sampel yang digunakan sebanyak 98 peserta didik. Penggunaan random sampling dengan alokasi proporsional dalam penelitian ini dengan cara mengacak peserta didik dari empat kelas untuk dipilih sebagai responden dikarenakan persebaran kemampuannya merata. Teknik pengambilan data menggunakan kuesioner untuk mengetahui respon peserta didik terhadap student engagement, kemampuan logis matematis, dan persepsi mengenai kompetensi guru. Kuesioner yang digunakan adalah kuesioner tertutup dan terbuka. Teknik analisis data menggunakan analisis regresi berganda, regresi moderasi, uji F, dan uji T. 


\section{HASIL DAN PEMBAHASAN}

Dalam penelitian ini menggunakan uji analisis regresi berganda. Berikut merupakan hasil pengujian regresi berganda:

Tabel 2. Analisis Regresi Berganda

\begin{tabular}{llccc}
\hline & \multicolumn{1}{c}{ Model } & $B$ & $\mathrm{~T}$ & Sig \\
\hline 1 & Constant & 54,467 & 3,517 &, 001 \\
& Keterlibatan peserta didik &, 486 & 2,264 &, 026 \\
& Kemampuan logis matematis &, 719 & 2,563 &, 012 \\
& Persepsi mengenai kompetensi guru &, 628 & 2,350 &, 021 \\
\hline
\end{tabular}

Pada tabel 2. diketahui nilai konstanta sebesar 54,467. Nilai koefisien untuk variabel keterlibatan peserta didik (X1) sebesar 0,486 dengan $t_{\text {hitung }}=2,264>t_{\text {tabel }} 1,985$ dan nilai signifikansi $=0,026<$ alpha $(0,05)$ berarti $\mathrm{H} 0$ ditolak dan $\mathrm{H} 1$ diterima, sehingga dapat disimpulkan bahwa terdapat pengaruh antara keterlibatan peserta didik terhadap prestasi belajar. Koefisien variabel kemampuan logis matematis sebesar 0,719 dengan $t_{\text {hitung }}=2,563>$ $t_{\text {tabel }}$ 1,985 dan nilai signifikansi $=0,012<$ alpha 0,05 berarti $\mathrm{H} 0$ ditolak dan H1 diterima, sehingga dapat disimpulkan bahwa terdapat pengaruh yang positif dan signifikan antara kemampuan logis matematis terhadap prestasi belajar. Sedangkan nilai koefisien variabel persepsi mengenai kompetensi guru $(Z)$ sebesar 0,628 dengan $t_{\text {hitung }}=2,350>t_{\text {tabel }}$ 1,9850 dan nilai signifikansi $=$ 0,021 berarti H0 ditolak dan H1 diterima, sehingga dapat disimpulkan bahwa terdapat pengaruh yang positif dan signifikan antara persepsi mengenai kompetensi guru terhadap prestasi belajar.

Tabel 3. Analisis Regresi Linier Variabel Moderasi X1 dan Z

\begin{tabular}{lllll}
\hline & \multicolumn{1}{c}{ Model } & \multicolumn{1}{c}{$B$} & T & \multicolumn{1}{c}{ Sig } \\
\hline 1 & Constant & 79,397 & 2,752 &, 007 \\
& Keterlibatan peserta didik (X1) & $-1,398$ & $-1,436$ &, 154 \\
& Persepsi mengenai kompetensi guru (Z) &,- 617 &,- 770 &, 443 \\
& Interaksi_X1Z &, 055 & 2,169 &, 033 \\
\hline
\end{tabular}

Berdasarkan tabel 3. Analisis regresi moderasi dengan metode interaksi diketahui hasil pengujian Interaksi hasil perkalian variabel X1 (keterlibatan peserta didik) dengan Z (persepsi mengenai kompetensi guru) menggunakan uji interaksi (MIRA) didapatkan hasil analisis regresi dalam persamaan berikut:

$$
\text { Y (Prestasi Belajar) = 79,397-1,398 X1-0,617 Z+0,055 Interaksi_X1Z }
$$

Berdasarkan persamaan tersebut dapat dianalisis bahwa (1) Nilai konstan pada hasil pengujian tersebut adalah 79,397 menunjukkan bahwa jika keterlibatan peserta didik, persepsi 
mengenai kompetensi guru, dan interaksi antara $\mathrm{X} 1 * \mathrm{Z}$ dalam keadaan konstan maka prestasi belajar diprediksi sebesar 79,397. (2) Pada pengujian tersebut diketahui nilai signifikansi pada Interaksi_X1Z $0,033<$ alpha $(0,05)$ dan nilai $t_{\text {hitung }}(2,169)>t_{\text {tabel }}(1.98498)$ hal tersebut menunjukkan bahwa variabel Z (persepsi mengenai kompetensi guru) merupakan variabel quasi moderasi karena memiliki nilai signifikansi interaksi X1.Z lebih kecil dari alpha dan nilai $t_{\text {hitung }}$ lebih besar dari $t_{\text {tabel. }}$. Maka dapat disimpulkan bahwa variabel $\mathrm{Z}$ (persepsi mengenai kompetensi guru) mampu memperkuat pengaruh keterlibatan peserta didik terhadap prestasi belajar sekaligus menjadi variabel independen yang berpengaruh terhadap prestasi belajar.

Tabel 4. Analisis Regresi Linier Variabel Moderasi X2 dan Z

\begin{tabular}{llccc}
\hline \multicolumn{1}{c}{ Model } & $B$ & $\mathrm{~T}$ & Sig \\
\hline 1 & Constant & 94,180 & 2,914 &, 004 \\
& Keterlibatan peserta didik (X1) & $-1,623$ & $-1,557$ &, 123 \\
& Persepsi mengenai kompetensi guru (Z) & $-1,368$ & $-1,488$ &, 140 \\
& Interaksi_X1Z &, 068 & 2,525 &, 013 \\
\hline
\end{tabular}

Berdasarkan tabel 4. Analisis regresi moderasi dengan metode interaksi Berdasarkan tabel 4. diketahui hasil pengujian Interaksi hasil perkalian variabel X1 (keterlibatan peserta didik) dengan $\mathrm{Z}$ (persepsi mengenai kompetensi guru) didapatkan hasil analisis regresi dalam persamaan berikut:

Y (Prestasi Belajar) = 94,180-1,623 X2-1,368 Z+0,068 Interaksi_X1Z

Berdasarkan persamaan tersebut dapat dianalisis bahwa (1) Nilai konstan pada hasil pengujian tersebut adalah 94,180 menunjukkan bahwa jika kemampuan logis matematis, persepsi mengenai kompetensi guru, dan interaksi antara $\mathrm{X} 1 * \mathrm{Z}$ dalam keadaan konstan maka prestasi belajar diprediksi sebesar 94,180. (2) Berdasarkan pengujian tersebut diketahui nilai signifikansi pada Interaksi_X1Z 0,013 < alpha $(0,05)$ dan nilai $t_{\text {hitung }}(2,525)>t_{\text {tabel }}(1.98498)$ hal tersebut menunjukkan bahwa variabel Z (persepsi mengenai kompetensi guru) merupakan quasi moderasi karena memiliki nilai signifikansi interaksi X2.Z lebih kecil dari alpha dan nilai $t_{\text {hitung }}$ lebih besar dari $t_{\text {tabel. }}$. Maka dapat disimpulkan bahwa variabel $\mathrm{Z}$ (persepsi mengenai kompetensi guru) mampu memperkuat pengaruh keterlibatan peserta didik terhadap prestasi belajar sekaligus menjadi variabel independen yang berpengaruh terhadap prestasi belajar.

\section{Uji T Parsial}

Pada tabel 2. Analisis regresi berganda didapatkan nilai $T_{\text {hitung }}(2,264)>T_{\text {tabel }}$ (1.98498) dengan Df (k-3) dengan tingkat signifikansi $(0,026)<$ alpha $(0,05)$ pada variabel X1 keterlibatan peserta didik, nilai $\mathrm{T}_{\text {hitung }}(2,563)>\mathrm{T}_{\text {tabel }}(1.98498)$ dengan $\mathrm{Df}(\mathrm{k}-3)$ dengan tingkat signifikansi $(0,012)<$ alpha $(0,05)$ pada variabel X2 kemampuan logis matematis, nilai $\mathrm{T}_{\text {hitung }}(2,350)>\mathrm{T}_{\text {tabel }}$ 
(1.98498) dengan Df (k-3) dengan tingkat signifikansi $(0,021)<$ alpha $(0,05)$ pada variabel Z persepsi mengenai kompetensi guru. Pada ketiga hasil pengujian tersebut diketahui masingmasing variabel memiliki nilai $\mathrm{T}_{\text {hitung }}>\mathrm{T}_{\text {tabel }}$ dan tingkat signifikansi $<$ alpha, berdasarkan hasil pengujian tersebut dapat disimpulkan bahwa variabel X1 keterlibatan peserta didik, variabel X2 kemampuan logis matematis, variabel Z persepsi mengenai kompetensi guru berpengaruh secara parsial terhadap prestasi belajar.

Pada tabel 3. Analisis regresi linier variabel moderasi X1 dan $\mathrm{Z}$ diketahui nilai $\mathrm{T}_{\text {hitung }}$ $(2,169)>T_{\text {tabel }}(1,98498)$ dengan Df $(k-3)$ dengan tingkat signifikansi $(0,033)<$ alpha $(0,05)$, serta pada tabel 4. Analisis regresi linier variabel moderasi X2 dan $\mathrm{Z}$ diketahui nilai $\mathrm{T}_{\text {hitung }}(2,525)>$ $\mathrm{T}_{\text {tabel }}(1,98498)$ dengan Df $(\mathrm{k}-3)$ dengan tingkat signifikansi $(0,013)<$ alpha $(0,05)$. Berdasarkan hasil pengujian tersebut dapat disimpulkan bahwa variabel $\mathrm{Z}$ persepsi mengenai kompetensi guru dapat memoderasi pengaruh variabel X1 keterlibatan peserta didik dan variabel X2 kemampuan logis matematis terhadap prestasi belajar.

Tabel 5. Anova Regresi Berganda

\begin{tabular}{llccccc}
\hline & & Sum of & & Mean & & \\
Model & & Squares & Df & Square & $F$ & Sig. \\
\hline 1 & Regression & 4224,607 & 3 & 1408,202 & 70,037 &, $000 \mathrm{~b}$ \\
& Residual & 1890,015 & 94 & 20,107 & & \\
& Total & 6114,622 & 97 & & & \\
& & & & & \\
\hline
\end{tabular}

Berdasarkan tabel 5. ANOVA masing-masing diperoleh $F_{\text {hitung }}$ sebesar 70,037 dan 73,257 sedangkan $\mathrm{F}_{\text {tabel }}$ dengan derajat kebebasan $: \mathrm{df}: \alpha, \mathrm{k}-1, \mathrm{n}-\mathrm{k}=4-1,98-3=3,95$ sebesar 2,77 dengan nilai signifikansi 0,000 karena nilai $F_{\text {hitung }}>$ nilai $F_{\text {tabel }}$ dan nilai signifikansinya lebih kecil dari 0,05 maka dapat disimpulkan bahwa keterlibatan peserta didik, kemampuan logis matematis, dan persepsi mengenai kompetensi guru, dan nilai interaksi X1Z, dan Interaksi X2Z menunjukkan model yang cocok digunakan ( $f i t$ ) dan secara simultan berpengaruh terhadap prestasi belajar.

\section{PEMBAHASAN}

\section{Pengaruh Keterlibatan Peserta Didik terhadap Prestasi Belajar}

Hasil penelitian menunjukkan bahwa keterlibatan peserta didik berpengaruh positif terhadap prestasi belajar dengan kontribusi dan dominasi terendah. Hal tersebut dikarenakan keterlibatan peserta didik bukan merupakan indikator aplikatif yang berhubungan langsung pada saat evaluasi atau ujian dilakukan, melainkan sebagai sikap dan determinasi yang ditunjukkan peserta didik untuk memperoleh prestasi belajar. Sikap dan determinasi tersebut sesuai dengan teori dalam Slameto (2019:25) menjelaskan bahwa sikap yang ditunjukkan oleh peserta didik merupakan bentuk penghargaan terhadap tugas (task value) dan determinasi diri (self determination). Beberapa sikap dan indikator yang ditunjukkan oleh peserta didik 
mendukung pengaruh positif keterlibatan peserta didik terhadap prestasi adalah peserta didik yang memiliki keterlibatan atau keterikatan yang baik akan memiliki keterlibatan dengan sekolah, keterlibatan secara kognitif, keterlibatan secara emosional, dan keterlibatan secara perilaku yang baik.

Selain itu, keterlibatan dengan kelas yang ditunjukkan oleh peserta didik di MAN 1 Banyumas pada sikap, pikiran (kognitif), dan perilaku yang partisipasif dan turut menjaga kondusifitas kelas dengan tidak membuat kegaduhan, memikirkan hal lain di luar mata pelajaran, mengantuk saat pelajaran berlangsung, bermain gawai, tidak merasakan bosan, tidak merasa terbebani saat diberikan tugas, serta mampu mengatasi gangguan saat pelajaran berlangsung. Hal tersebut menurut Gunuc (2014) dan Naufall (2011) menunjukkan bahwa peserta didik MAN 1 Banyumas telah memiliki keterlibatan dengan kelas (class engagement). Selain itu, hasil penelitian ini didukung oleh penelitian yang dilakukan oleh Bariyah et.al (2017) yang menyatakan bahwa keterlibatan peserta didik memberikan pengaruh yang positif dan signifikan terhadap prestasi belajar sosiologi. Sedangkan Ayodele (2014) menyatakan bahwa lamanya keterlibatan peserta didik memberikan pengaruh yang positif dan signifikan terhadap prestasi belajar pada mata pelajaran kimia.

\section{Pengaruh Kemampuan Logis Matematis terhadap Prestasi Belajar}

Hasil penelitian menunjukkan bahwa kemampuan logis matematis berpengaruh secara positif terhadap prestasi belajar, serta menjadi variabel dengan tingkat kontribusi dan dominasi tertinggi yang mempengaruhi prestasi belajar. Slameto (2010:54) yang menjelaskan bahwa faktor yang dapat mempengaruhi prestasi belajar peserta didik adalah faktor intelegensi dan bakat yang diimplementasi secara langsung terhadap pemahaman konseptual dan aplikatif pada proses pembelajaran sampai evaluasi pelajaran ekonomi. Hal tersebut menunjukkan bahwa kemampuan logis matematis peserta didik memiliki pengaruh besar dalam meningkatkan prestasi belajar.

Hasil penelitian ini didukung oleh penelitian yang dilakukan oleh Sihombing (2016) yang menyatakan bahwa kecerdasan matematis-logis dan gaya belajar kinestetik peserta didik menunjukkan pengaruh positif dan signifikan terhadap prestasi belajar ekonomi peserta didik SMA Negeri 4 Medan. Serta dalam penelitian Pasaribu (2017) yang menyatakan bahwa kemandirian belajar dan kecerdasan logis matematis menunjukkan hubungan yang positif dan signifikan terhadap prestasi belajar ekonomi peserta didik SMA Negeri 1 Laguboti.

\section{Pengaruh Persepsi mengenai Kompetensi Guru terhadap Prestasi Belajar}

Hasil penelitian menunjukkan bahwa terdapat pengaruh yang positif antara persepsi mengenai kompetensi guru terhadap prestasi belajar dengan kontribusi dan dominasi menengah. Dalam teori belajar sosial (social cognitive) menjelaskan bahwa peran guru berfungsi sebagai stimulan peserta didik untuk berprestasi dan tidak berhubungan langsung dengan proses untuk 
mendapatkan outcome atau hasil belajar yang didapatkan peserta didik melalui evaluasi pembelajaran. (Slameto, 2019:25). Hal tersebut menunjukkan bahwa seorang guru yang kompeten mampu untuk menstimulasi pembelajaran agar mendapatkan prestasi belajar yang optimal. Beberapa sikap dan indikator dalam penelitian ini yang menunjukkan persepsi peserta didik dalam menilai guru telah memiliki kompetensi pedagogik, kompetensi profesional, kompetensi sosial, dan kompetensi kepribadian yang baik.

Hasil penelitian yang dilakukan oleh penulis didukung oleh penelitian yang dilakukan oleh Hakim (2015) yang menyatakan bahwa kompetensi guru menunjukkan pengaruh positif terhadap prestasi belajar peserta didik. Serta dalam penelitian Inayah et.al (2012) yang menyatakan kompetensi guru berpengaruh secara langsung terhadap prestasi belajar mata pelajaran ekonomi. Kedua penelitian tersebut sesuai dengan yang dilakukan oleh penulis yang ditunjukkan oleh hasil kuesioner dari mayoritas peserta didik menyetujui bahwa guru yang kompeten mampu untuk menstimulasi peserta didik untuk mendapatkan prestasi belajar yang optimal. Guru yang kompeten setidaknya memiliki kompetensi pedagogik, kompetensi profesional, kompetensi kepribadian, dan kompetensi sosial yang baik.

\section{Pengaruh Keterlibatan Peserta Didik terhadap Prestasi Belajar Dimoderasi Persepsi mengenai Kompetensi Guru}

Berdasarkan hasil pengujian diketahui bahwa terdapat pengaruh positif antara keterlibatan peserta didik terhadap prestasi belajar akan lebih baik jika persepsi kompetensi guru dari peserta didik juga baik. Hal tersebut menunjukkan bahwa kompetensi guru yang baik menurut persepsi peserta didik mampu untuk meningkatkan tingkat keterlibatan peserta didik dengan sekolah, keterlibatan peserta didik secara kognitif atau pengetahuan, keterlibatan peserta didik secara emosional, dan keterlibatan peserta didik secara perilaku. Seorang guru yang kompeten mampu untuk menggunakan media, metode, dan instrumen evaluasi yang sesuai (kompetensi pedagogik), mengelola kelas dengan baik (kompetensi profesional), berkomunikasi secara intens (kompetensi sosial), dan memberikan contoh yang baik kepada peserta didik (kompetensi kepribadian).

Hasil penelitian yang dilakukan oleh penulis didukung oleh penelitian Sayuwaktini et al. (2015), Meilinda dan Aulia (2017), dan Kheruniah (2013) yang menunjukkan terdapat pengaruh positif dan signifikan antara kompetensi guru dengan keterlibatan peserta didik. Selain itu, dalam penelitian Mujianto (2010) menjelaskan bahwa persepsi siswa tentang kompetensi pedagogik guru berpengaruh signifikan terhadap hasil belajar dan motivasi belajar peserta didik. dari beberapa penelitian tersebut menjelaskan bahwa persepsi mengenai kompetensi guru yang dimiliki oleh peserta didik mampu untuk menstimulasi dan meningkatkan keterlibatan peserta didik. serta keterlibatan peserta didik tersebut secara langsung berkontribusi dan memiliki pengaruh untuk meningkatkan prestasi belajar. 


\section{Pengaruh Kemampuan Logis Matematis terhadap Prestasi Belajar Dimoderasi Persepsi mengenai Kompetensi Guru}

Berdasarkan hasil pengujian diketahui bahwa terdapat pengaruh positif antara kemampuan logis matematis terhadap prestasi belajar akan lebih baik jika persepsi kompetensi guru dari peserta didik juga baik. Hal tersebut menunjukkan bahwa kompetensi guru yang baik menurut persepsi peserta didik mampu menstimulasi kemampuan logis matematis melalui penggunaan media, metode, dan alat evaluasi yang sesuai (kompetensi pedagogik), pengelolaan kelas yang baik (kompetensi profesional), kejelasan bahasa intruksional (kompetensi sosial), dan memberikan motivasi kepada peserta didik (kompetensi kepribadian). Guru yang memiliki kompetensi cenderung mudah untuk memberdayakan dan mengembangkan (empowering and developing) peserta didik melalui pengelolaan kelas yang baik. Pengelolaan tersebut bertujuan untuk memobilisasi sumberdaya yang dimiliki oleh peserta didik berupa kemampuan atau kecerdasan logis matematis (Nessipbayeva, 2012:149).

Hasil penelitian tersebut didukung oleh penelitian dari Kunter et al. (2013) yang menyebutkan bahwa kompetensi atau profesionalitas guru dapat meningkatkan hasil belajar dan kemampuan logis matematis peserta didik. Selain itu, dalam penelitian Jentsch dan Schlesinger (2017) yang menjelaskan bahwa pengelolaan kelas, dukungan pembelajaran mandiri, aktivasi kognitif, dan kualitas pembelajaran menunjukkan pengaruh yang positif terhadap prestasi belajar peserta didik.

\section{KESIMPULAN}

Berdasarkan hasil penelitian dan analisis data yang diuraikan, maka dapat ditarik kesimpulan bahwa : (1) keterlibatan peserta didik berpengaruh positif dan signifikan terhadap prestasi belajar (2) kemampuan logis matematis berpengaruh positif dan signifikan terhadap prestasi belajar (3) persepsi mengenai kompetensi guru berpengaruh positif dan signifikan terhadap prestasi belajar (4) persepsi mengenai kompetensi guru memoderasi pengaruh keterlibatan peserta didik terhadap prestasi belajar (5) persepsi mengenai kompetensi guru memoderasi pengaruh kemampuan logis matematis terhadap prestasi belajar.

\section{DAFTAR PUSTAKA}

Ahmad, Deni Nasir. (2018). Persepsi Siswa tentang Kompetensi Pedagogik Guru dan Motivasi Belajar dalam Meningkatkan Keterampilan Berpikir Analitik. Jurnal Pendidikan.Universitas PGRI Indraprasta.

Amstrong, Thomas. (2014). Multiple Intelligences in the Classroom. New York, USA: Tarcher. Asrul. (2014). Evaluasi Pembelajaran. Bandung: Cita Pustaka Media. 
Barkley, Elisabeth F. (2009). Student Engagement Techniques: A Handbook for College Faculty. California, USA: The Jossey Bass.

Bariyah, Ikhtarotul dan Pierewan, Adi Cilik. (2017). Keterlibatan Siswa (Student Engagement) terhadap Prestasi Belajar. Jurnal Pendidikan. Universitas Negeri Yogyakarta.

Cooper, James. (2010). Classroom teaching Skill 6th Edition. California USA: Wadsworth, Cengage Learning.

Creemers et.al. (2013). Teacher Professional Development for Improving Quality of Teaching. New York, USA: Springer Publishing.

Gardner, Howard. (1993). Frames of Mind: The Theory of Multiple Intelligences. New York, USA: Basic Books

Gunuc, Selim. (2014). The Relationships between Student Engagement and Their Academic Achievement. Jurnal Pendidikan. Universitas Yuzuncu Yil Turki.

Gunuc, Selim. dan Kuzu, A. (2014). Student engagement scale: Development reliability and validity. Assessment \& Evaluation in Higher Education. . Turki : Anadolu University.

Hakim, Adnan. (2015). Contribution of Competence Teacher (Pedagogical, Personality, Professional Competence and Social) On the Performance of Learning. Jurnal pendidikan. The International Journal Of Engineering And Science (IJES).

Jentsch, Armin dan Schlesinger, Lena. 2017. Measuring instructional quality in mathematics education. Jurnal Pendidikan. Universitas Hamburg.

Kunter, Mareike et al. (2013). Professional Competence of Teachers: Effects on Instructional Quality and Student Development. Jurnal Psikologi Pendidikan. American Psychological Association.

Kheruniah, Ade Een. (2013). A Teacher Personality Competence Contribution To A Student Study Motivation And Discipline To Fiqh Lesson. Jurnal Pendidikan. International Journal of Scientific and Technology Research.

Meilinda, Fitri dan Aulia, Farah. (2017). Kontribusi Persepsi tentang Kompetensi Pedagogik Guru Terhadap Keterikatan Siswa pada Pelajaran Matematika. Jurnal Pendidikan. Universitas Negeri Padang.

Pasaribu, Jojor Delima. (2016). Hubungan Kemandirian Belajar dan Kecerdasan Logis Matematis dengan Prestasi Belajar Ekonomi Siswa Kelas XI IPS SMA Negeri 1 Laguboti Tahun Pembelajaran 2015/2016. Skripsi. Universitas Negeri Medan.

Prihantoro, C. Rudi et al. (2019). The Effect of Teacher Competency and Teaching Commitment to Student Learning Results Machining Engineering Skills Program. Jurnal Pendidikan. Universitas Negeri Jakarta.

Sihombing, Andrio Gianta. (2016). Pengaruh Kecerdasan Matematis Logis dan Gaya Belajar Kinestetik Siswa terhadap Prestasi Belajar Ekonomi Siswa Kelas X SMA Negeri 4 Medan Tahun Ajaran 2016/2017. Skripsi. Universitas Negeri Medan.

Wulandari, Denik. (2012). Pengaruh Kompetensi Pedagogik dan Kompetensi Profesional Guru terhadap Economic Literacy melalui Prestasi Belajar Siswa Kelas XII IPS di SMA Kota Malang. Jurnal Pendidikan. Universitas Negeri Malang. 
Wulansari, Mayang dan Hakim, Lukman. (2015). Pengaruh Kecerdasan Logis-Matematis, Hasil Belajar Pengantar Akuntansi, dan Minat Belajar terhadap Tingkat Pemahaman Akuntansi. Jurnal Pendidikan. Universitas Negeri Surabaya.

Salisah, Nikmah Hadiati . (2015). Psikologi Komunikasi: buku perkuliahan Program S-1 Program Studi Ilmu Komunikasi Fakultas Dakwah dan Ilmu Komunikasi IAIN Sunan Ampel Surabaya. Surabaya: IAIN Press.

Slameto. (2010). Belajar dan faktor-faktor yang Mempengaruhinya. Jakarta: PT. Rineka Cipta.

Slameto. (2019). Partisipasi Orang Tua dan Faktor Latar Belakang yang Berpengaruh terhadap Prestasi Belajar Siswa SMA. Jakarta : CV Qiara Media.

OECD-PISA. (2018). Indonesia's The Programme for International Student Assessment (PISA) Report. [tersedia pada] https://www.oecd.org/pisa/publications/PISA2018_CN_IDN.pdf [Diakses pada 17 Juni 2020].

Pemerintah Republik Indonesia. (2005). Undang-undang No 14 tahun 2005 tentang Guru dan Dosen. [Tersedia pada] https://ppg.kemdikbud.go.id/download/undang-undangrepublik-indonesia-nomor-14-tahun-2005-tentang-guru-dan-dosen/ [Diakses pada 18 Juni 2020].

TALIS-PISA. (2018). A Teachers' Guide to TALIS 2018. Annual Report. The Programme for International Student Assessment (PISA). [Tersedia pada] https://www.oecd.org/education/talis/TALIS-Teachers-Guide-to-TALIS-2018-VolI_ENG.pdf [Diakses pada 5 Juli 2020]. 